\title{
A facile, rapid, one-pot regio/stereoselective synthesis of 2-iminothiazolidin-4-ones under solvent/scavenger-free conditions
}

\author{
Murugan Sathishkumar, Sangaraiah Nagarajan, Poovan Shanmugavelan, \\ Murugan Dinesh and Alagusundaram Ponnuswamy*
}

\section{Full Research Paper}

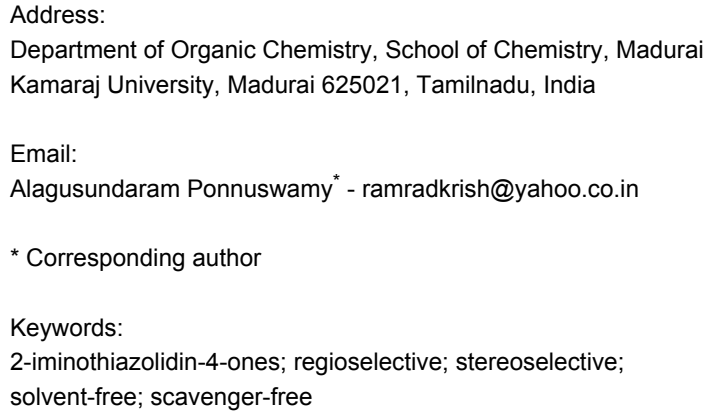

\author{
Beilstein J. Org. Chem. 2013, 9, 689-697. \\ doi:10.3762/bjoc.9.78 \\ Received: 07 December 2012 \\ Accepted: 17 March 2013 \\ Published: 10 April 2013 \\ Associate Editor: M. S. Sherburn \\ (c) 2013 Sathishkumar et al; licensee Beilstein-Institut. \\ License and terms: see end of document.
}

\begin{abstract}
A rapid and efficient one pot solvent/scavenger-free protocol for the synthesis of 2-iminothiazolidin-4-ones has been developed. Interestingly, the regio/stereoselective synthesis affords the regioisomeric (Z)-3-alkyl/aryl-2-(2-phenylcyclohex-2-enylimino)thiazolidin-4-one as the sole product in good yield. The selectivities observed have been rationalized based on the relative magnitude of the allylic strains developed during the course of the reaction. This is the first report wherein the impact of allylic strains in directing the regiocyclization has been noted.
\end{abstract}

\section{Introduction}

Thiazolidin-4-one derivatives are well known for their bioactivities such as antidiabetic [1], anticancer [2], calcium-channel blocker [3,4], platelet activating factor (PAF) antagonist [5] and anti-HIV [6] activity. In addition, 2-iminothiazolidin-4-ones exhibit remarkable hypnotic [7,8], antitubercular [9], cardiovascular [10] and cyclooxygenase (COX) inhibitory [11] activities (Figure 1).

A common strategy involved in the prevailing synthetic protocols for 2-iminothiazolidin-4-ones [12-14] is the cyclization of thioureas with $\alpha$-halocarboxylic acids [15] or acyl halides
$[16,17]$ or carboxylic esters [18]. These protocols are generally solution phase methods using organic solvents and acid scavengers. In the present scenario, such protocols may not be recommended by the principles of green chemistry. Consequently, the search for simple and efficient environmentally friendly methodologies for the synthesis of 2-iminothiazolidin4-ones is worth attempting.

In this regard, and in continuation of our recent reports on the solvent-free synthesis of amides [19,20], thioamides [21], cyclic imides [22], thiazolidin-4-ones [23], spirothiazolidin-4-ones 
<smiles>O=C(O)CC1SC(=NC2CCCCC2)N(c2ccccc2)C1=O</smiles>

Cardiovascular activity<smiles>O=C1CS/C(=N/c2ccccc2)N1c1ncccn1</smiles>

Hypnotic activity<smiles>CCN1C(=O)/C(=C2/C=CC(OC)=CC2)S/C1=N\c1ccccc1</smiles><smiles>N=C1SCC(=O)N1CC(O)[Al]</smiles>

Antihypertensive activity

Figure 1: Medicinally relevant 2-iminothiazolidin-4-ones.

[24], 1,2,3-triazoles [25], 1,2,3-triazolylchalcones [26], and 1,2,3-triazolyldihydropyrimidine-2-thiones [27], we herein present a one-pot solvent/scavenger-free synthetic protocol for 2-iminothiazolidin-4-ones. This environmentally benign method avoids toxic organic solvents and acid scavengers, the details of which are presented below.

\section{Results and Discussion}

At the outset, optimization of the one-pot reaction was attempted by varying the solvents and using triethylamine as the

acid scavenger (Table 1). The reaction was also attempted under solvent-free conditions. The latter was more promising in the sense that the reaction was very rapid affording the product $\mathbf{4 f}$ in 15-20 min (Table 1, entries 7 and 8) compared to 2-6 h (Table 1, entries 1-6) in solvents. The structure of the product $4 \mathbf{f}$ was assigned as (Z)-2-(2-phenylcyclohex-2-enylimino)-3-ptolylthiazolidin-4-one based on the single-crystal XRD data $[28,29]$ of its analogues $(\mathbf{4} \mathbf{c}$ and $\mathbf{4 j})$.

Though the rate of reaction rate could be accelerated, the yield of 2-iminothiazolidin-4-one $4 \mathbf{f}$ was not good (41-66\%) under both solution-phase and solvent-free conditions. Hence, as an attempt to optimize the yield, the solvent-free protocol was screened with and without the acid scavenger. Hereto, the yield of the product was poor (Table 2). Thus, the screening indicated that the scavengers had no positive, but rather an impeding effect. To develop an insight in this regard, a plausible mechanism of the reaction in the presence of the acid scavenger was proposed (Scheme 1).

From the mechanism, it can be envisaged that the acid scavenger may neutralize the $\mathrm{HCl}$ (that is generated during the course of the reaction) or the iminium ions by deprotonation. Also, another possibility is that the use of base as the scavenger may lead to the acid-base reaction resulting in the formation of the carboxylate anion of one the starting materials viz. chloroacetic acid or the thiourea-chloroacetic acid coupled product. This may retard the direct amine-carboxylic acid coupling, thus decreasing the yield of the product.

Table 1: Optimization of solution-phase and solvent-free synthesis of 2-iminothiazolidin-4-one $\mathbf{4 f .}$

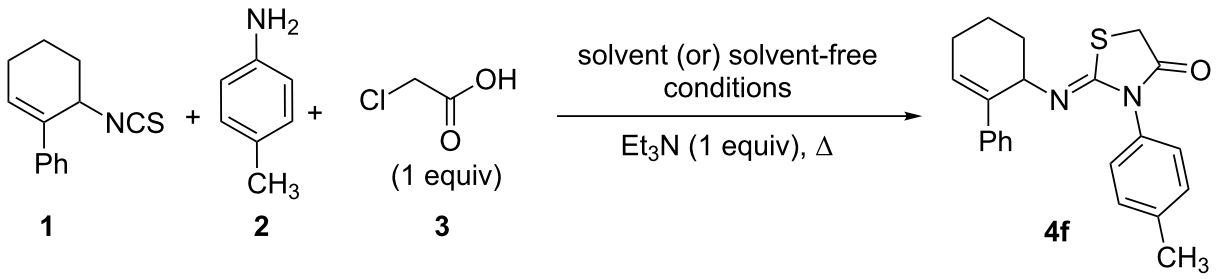

\begin{tabular}{lllll}
\hline Entry & Solvent & Temperature & Time \\
\hline 1 & ethanol & reflux & $4 \mathrm{~h}$ & 52 \\
2 & acetonitrile & reflux & $2 \mathrm{~h}$ & 66 \\
3 & dioxane & reflux & $4 \mathrm{~h}$ & 46 \\
4 & THF & reflux & $3 \mathrm{~h}$ & 51 \\
5 & acetonitrile/ethanol $(1: 1)$ & reflux & $3 \mathrm{~h}$ & 49 \\
6 & DCM & reflux & $6 \mathrm{~h}$ & 41 \\
7 & solvent-free & $80{ }^{\circ} \mathrm{C}$ & $20 \mathrm{~min}$ & 41 \\
8 & solvent-free & $100^{\circ} \mathrm{C}$ & $15 \mathrm{~min}$ & 54 \\
\hline
\end{tabular}

aYield of isolated product. 
Table 2: Screening of base and equivalents of chloroacetic acid in the solvent-free synthesis of 2-iminothiazolidin-4-one 4f.

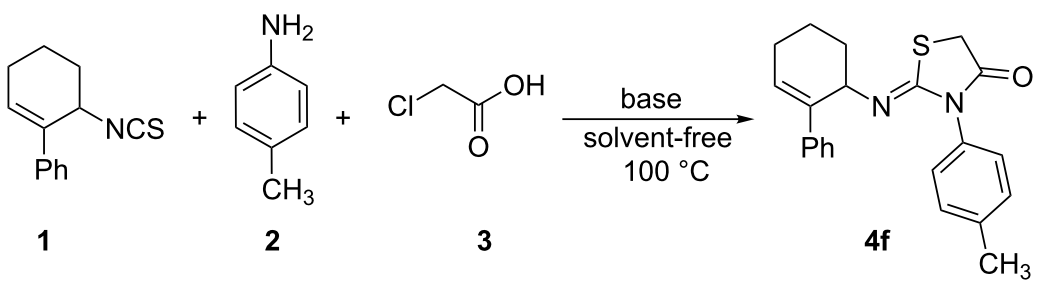

\begin{tabular}{lllll}
\hline Entry & Base & Base (equiv) & Chloroacetic acid (equiv) & Yield (\%) $^{\mathrm{a}}$ \\
\hline 1 & $\mathrm{Et}_{3} \mathrm{~N}$ & 1 & 1 & 41 \\
2 & $\mathrm{~K}_{2} \mathrm{CO}_{3}$ & 1 & 1 & 25 \\
3 & $\mathrm{~K}_{2} \mathrm{CO}_{3}$ & 1 & 2 & 35 \\
4 & $\mathrm{NaOH}$ & 1 & 2 & 24 \\
5 & pyridine & 1 & 2 & 57 \\
6 & - & - & 3 & 82 \\
\hline
\end{tabular}

aYield of the isolated product.

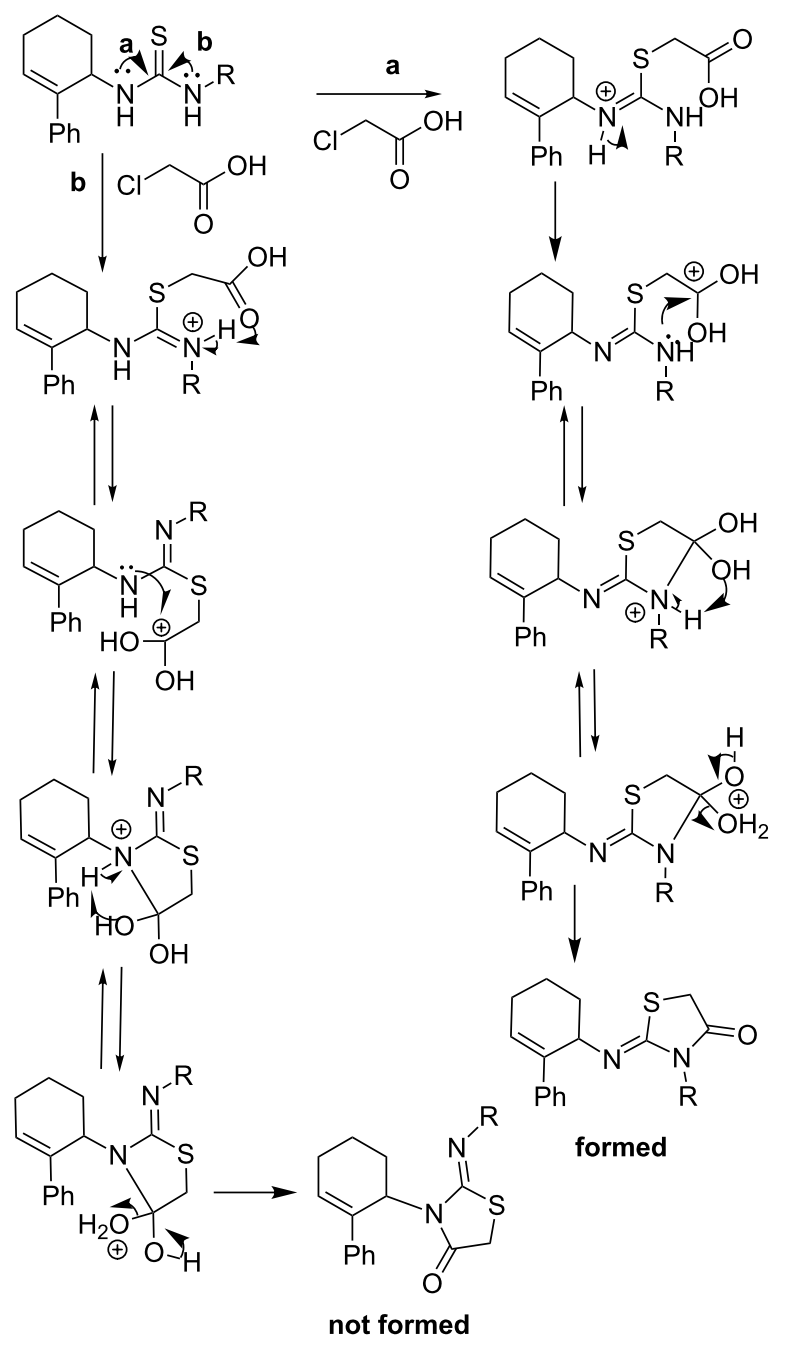

Scheme 1: Plausible mechanism.
In view of the above perception, the solvent-free protocol was screened with one equivalent or in the absence of acid scavenger and varying equivalents of chloroacetic acid at $100{ }^{\circ} \mathrm{C}$ (Table 2). The optimum conditions were found to be with 3 equivalents of chloroacetic acid in the absence of acid scavenger affording a good yield of 2-iminothiazolidin-4-one $\mathbf{4 f}$ (Table 2, entry 6).

In this context, it is pertinent to mention that while the prevailing solution-phase protocol [30-32] uses an acid scavenger, such as sodium hydroxide, triethylamine, pyridine or sodium acetate, the solvent-free methodology involved in the present investigation does not require any acid scavenger.

The scope of the new synthetic protocol was proved through the synthesis of a library of 2-iminothiazolidin-4-ones (Table 3). However, its limitations were realized when the synthesis of ortho-tolyl/1-napthyl analogues and the para-substituted $\left(\mathrm{NO}_{2}\right.$ and $\mathrm{COOH}$ ) phenyl analogues failed. Apparently, the reason for this can be attributed to the retardation of the nucleophilic attack of the amines on the isothiocyanate due to the steric effect (Figure 2) in the former, and decrease of the nucleo-

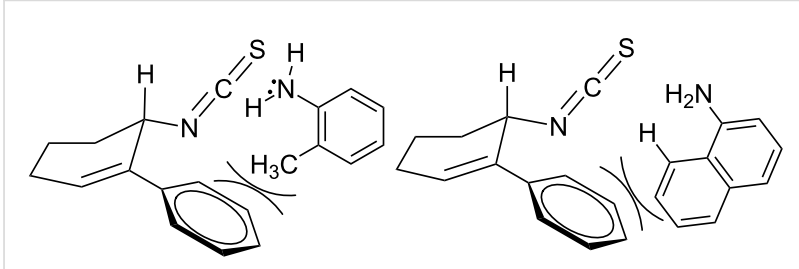

Figure 2: Retardation of the nucleophilic attack of amines on the isothiocyanate due to the steric effect. 
Table 3: Solvent/scavenger-free synthesis of 2-iminothiazolidin-4-ones $\mathbf{4 a - n}$.

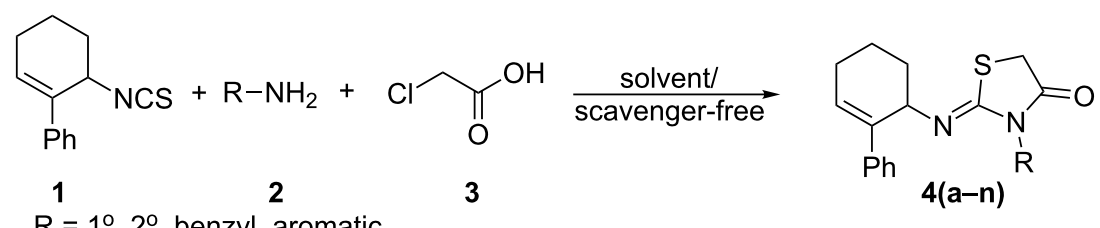

$\mathrm{R}=1^{\circ}, 2^{\circ}$, benzyl, aromatic

\begin{tabular}{|c|c|c|c|}
\hline Entry & Amine & Product & Yield $(\%)^{a}$ \\
\hline 1 & $\mathrm{CH}_{3} \mathrm{CH}_{2} \mathrm{NH}_{2}$ & $4 a$ & 79 \\
\hline 2 & $\mathrm{CH}_{3} \mathrm{CH}_{2} \mathrm{CH}_{2} \mathrm{CH}_{2} \mathrm{NH}_{2}$ & $4 b^{(C H}$ & 84 \\
\hline 3 & $\mathrm{H}_{2}$ & 4c & 87 \\
\hline 4 & & 4d & 84 \\
\hline 5 & & $4 e$ & 80 \\
\hline 6 & & $4 f$ & 82 \\
\hline 7 & & $4 \mathrm{~g}$ & 80 \\
\hline
\end{tabular}


Table 3: Solvent/scavenger-free synthesis of 2-iminothiazolidin-4-ones $\mathbf{4 a - n}$. (continued)

8<smiles>Nc1ccc(Cl)cc1</smiles>

9<smiles>COc1ccc(N)cc1</smiles>

10<smiles>Nc1ccc(Br)cc1</smiles>

11<smiles>Cc1ccccc1N</smiles>

12<smiles>Nc1cccc2ccccc12</smiles>

13<smiles>Cc1cccc(N)c1</smiles>

14<smiles>[X]c1ccc(N)cc1</smiles><smiles>O=C1CS/C(=N\C2CCCC=C2c2ccccc2)N1c1ccc(Cl)cc1</smiles>

4h<smiles>COc1ccc(N2C(=O)CSC2=NC2CCCC=C2c2ccccc2)cc1</smiles>

$4 i$<smiles>O=C1CSC(=NC2CCCC=C2c2ccccc2)N1c1ccc(Br)cc1</smiles>
81<smiles>Cc1ccccc1N1C(=O)CSC1=NC1CCCC=C1c1ccccc1</smiles>

4k<smiles>O=C1CS/C(=N\C2CCCC=C2c2ccccc2)N1c1cccc2ccccc12</smiles>

41<smiles>Cc1cccc(N2C(=O)CSC2=NC2CCCC=C2c2ccccc2)c1</smiles>
trace $4 \mathrm{~m}$<smiles>[X]c1ccc(N2C(=O)CSC2=NC2CCCC=C2c2ccccc2)cc1</smiles>

$4 n$

aYield of isolated product. 
philicity of the amines by the electron-withdrawing group in the latter, thus not affording the expected thiourea.

Having established the new protocol for the synthesis of 2-iminothiazolidin-4-ones, the method was extended to the rapid synthesis of a library of thiazolidinone derivatives (Table 4).

Further, it is pertinent to mention here the interesting regio/ stereoselectivity noted in the synthesis. Though the formation of

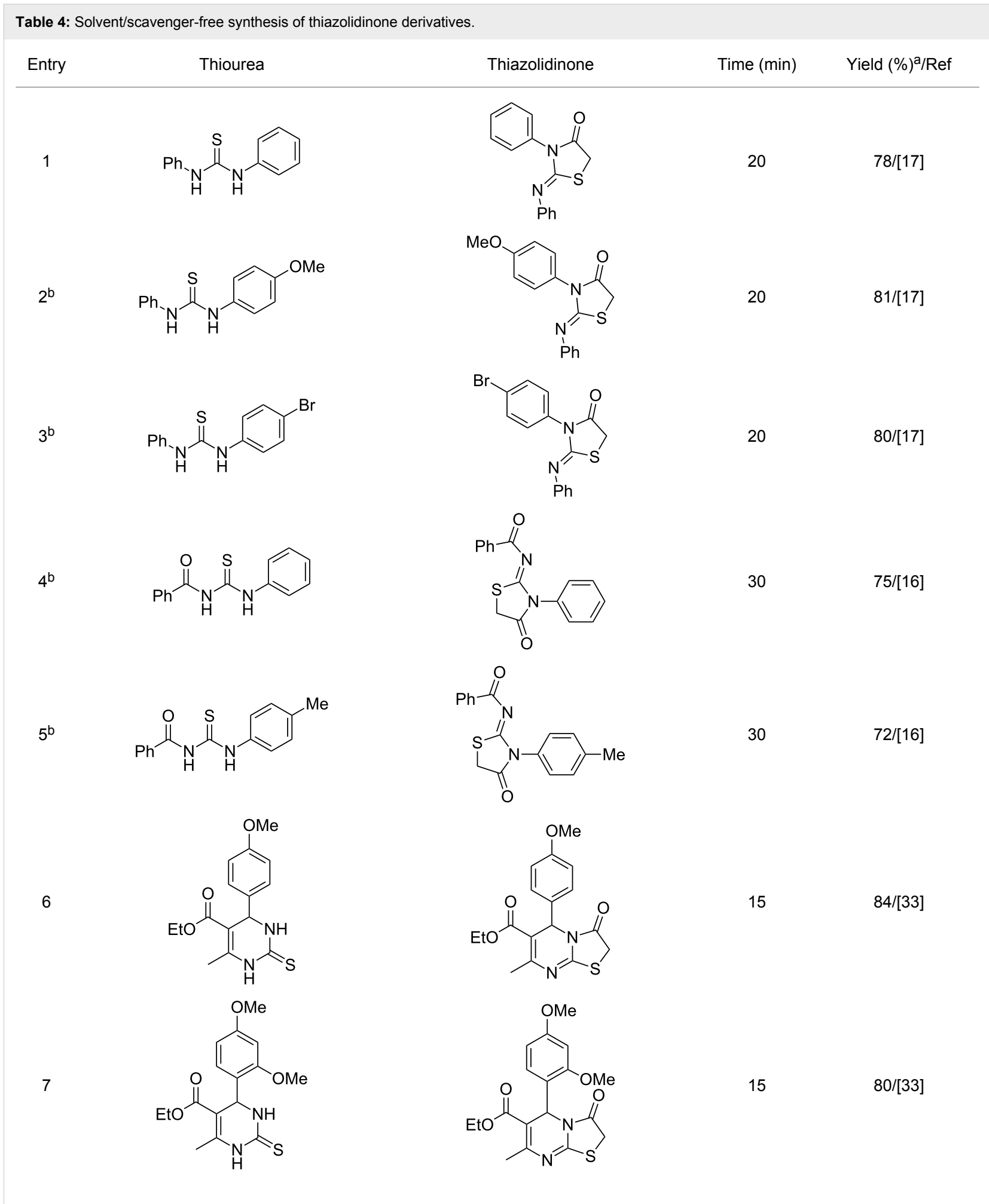


Table 4: Solvent/scavenger-free synthesis of thiazolidinone derivatives. (continued)

8<smiles>COc1ccc(C2NC(=S)NC(C)=C2C(C)=O)cc1</smiles>

9<smiles>COc1ccc(C2NC(=S)NC(C)=C2C(C)=O)c(OC)c1</smiles>

10<smiles>S=C1NC2=C(CCc3ccccc32)C(c2ccccc2)N1</smiles>

11<smiles>O=[N+]([O-])c1cccc(C2NC(=S)NC3=C2CCc2ccccc23)c1</smiles>

12<smiles>S=c1[nH]c2ccccc2[nH]1</smiles><smiles>COc1ccc(C2C(C(C)=O)=C(C)N=C3SCC(=O)N32)cc1</smiles><smiles>COc1ccc(C2C(C(C)=O)=C(C)N=C3SCC(=O)N32)c(OC)c1</smiles>

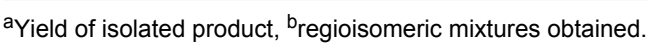

the four regio/stereoisomeric 2-iminothiazolidin-4-ones $\mathbf{4 a}, \mathbf{4 b}, \mathrm{A}^{1,3}$ ) developed during the course of the regiocyclization $\mathbf{5 a}$ and $\mathbf{5 b}$ is possible, it is novel to note that only one of them, (Scheme 2). viz. $\mathbf{4 b}$, is formed exclusively (Figure 3 ).

In this context, it is relevant to recall the literature reports on the The high regio/stereoselectivity of the reaction can be rationalized based on the relative magnitudes of allylic strains $\left(\mathrm{A}^{1,2}\right.$ and

factors directing the regioselectivity in the synthesis of 2-iminothiazolidin-4-ones. Only a couple of reports in this<smiles>CC1CC=C(c2ccccc2)C(N=C2SC(=O)CN2c2ccccc2)C1</smiles>

4a<smiles>O=C1CS/C(=N\C2CCCC=C2c2ccccc2)N1c1ccccc1</smiles>

4b<smiles>O=C1CS/C(=N\c2ccccc2)N1C1CCCC=C1P</smiles>

$5 a$

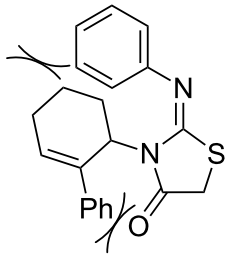

$5 b$

Figure 3: Possible regio/stereoisomeric products. 


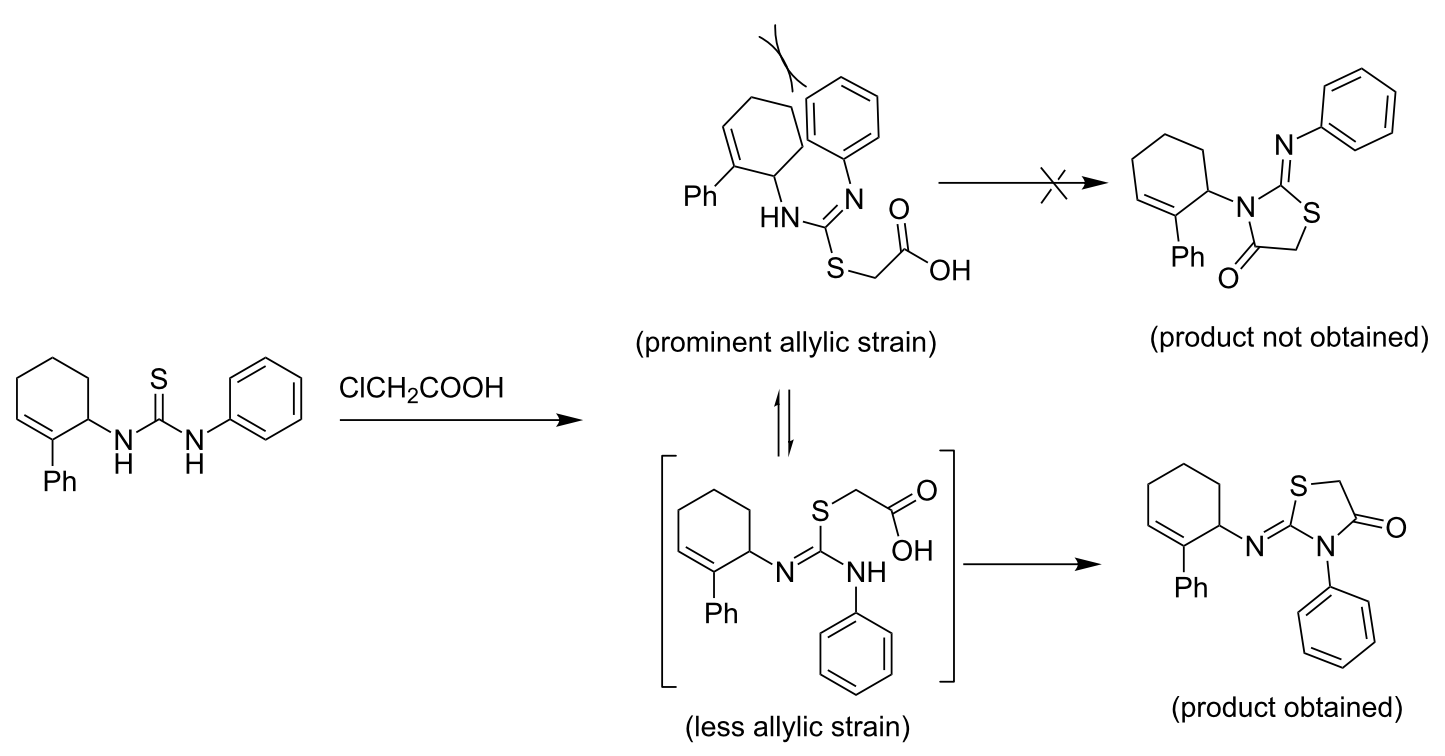

Scheme 2: Regioselective cyclization in 2-iminothiazolidin-4-one synthesis directed by allylic strains.

regard are available in the literature. While one of these reports suggests that the $\mathrm{p} K_{\mathrm{a}}[17]$ of amines directs the regioselectivity, another investigation indicates that the chelating effect [18] of the substituent directs the regiochemical outcome. In both the reports, two regioisomeric 2-iminothiazolidin-4-ones are obtained. Thus, the present investigation affording a single regioisomeric product exclusively is the first report wherein the allylic strains are noted to direct the high regioselectivity.

Finally, the stereoselective formation of the $(Z)$-stereoisomer is also explicable based on allylic strain, which is summarized in Figure 4.

\section{Conclusion}

In conclusion, a new solvent/scavenger-free synthetic protocol for 2-iminothiazolidin-4-ones has been reported. Unlike the prevailing solution-phase protocols employing organic solvents and acid scavengers, the present study avoids solvents and scavengers. The rate of the reaction is prominently enhanced under solvent-free conditions compared to that in the solution phase. Apparently, the intimacy of the highly polar reactants in the fused state in the absence of solvent may be responsible for the rate enhancement.

\section{Supporting Information}

\section{Supporting Information File 1}

Experimental procedures and product characterization for compounds $(\mathbf{4 a} \mathbf{a}-\mathbf{j})$.

[http://www.beilstein-journals.org/bjoc/content/ supplementary/1860-5397-9-78-S1.pdf]

\section{Acknowledgements}

The author MS thanks UGC, New Delhi for the award of a junior research fellowship and the Department of Science and Technology, New Delhi for funds under the IRHPA program providing the NMR facility.<smiles>O=C1CS/C(=N\C2CCCC=C2c2ccccc2)N1c1ccccc1</smiles>

Product obtained (less $A^{1,3}$ Strain)

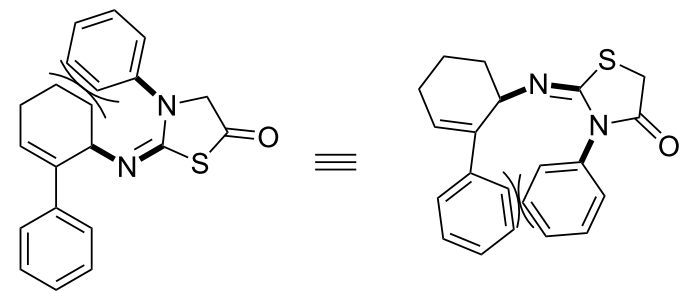

Product not obtained (prominent $A^{1,3}$ Strain)

Figure 4: Stereoselectivity of the reaction directed by $A^{1,3}$ strain. 


\section{References}

1. Ueno, H.; Oe, T.; Snehiro, I.; Nakamura, S. Preparation of 5-[2-naphthylmethyl(or methylene)]-thiazolidine-2,4-diones, 2-thioxy-thiazolidine-4-ones and $1 \mathrm{H}$-tetrazoles for reducing blood sugar and blood lipid levels. U.S. Patent 5,594,016, Jan 14, 1997.

2. Ebeid, M. Y.; Fathallah, O. A.; El-Zaher, M. I.; Kamel, M. M.; Abdon, W. A.; Anwar, M. M. Bull. Fac. Pharm. (Cairo Univ.) 1996, 34, 125-135.

3. Hara, A.; Suzuki, T.; Hashizume, H.; Shishido, N.; Nakamura, M.; Ushikubi, F.; Abiko, Y. Eur. J. Pharmacol. 1999, 385, 81-88. doi:10.1016/S0014-2999(99)00708-6

4. Kato, T.; Ozaki, T.; Tamura, K.; Suzuki, Y.; Akima, M.; Ohi, N. J. Med. Chem. 1999, 42, 3134-3146. doi:10.1021/jm9900927

5. Tanabe, Y.; Suzukamo, G.; Komuro, Y.; Imanishi, N.; Morooka, S.; Enomoto, M.; Kojima, A.; Sanemitsu, Y.; Mizutani, M. Tetrahedron Lett. 1991, 32, 379-382. doi:10.1016/S0040-4039(00)92633-9

6. Rawal, R. K.; Prabhakar, Y. S.; Katti, S. B.; De Clercq, E. Bioorg. Med. Chem. 2005, 13, 6771-6776. doi:10.1016/j.bmc.2005.07.063

7. Chaudhari, S. K.; Verma, M.; Chaturvedi, A. K.; Parmar, S. S. J. Pharm. Sci. 1975, 64, 614-617. doi:10.1002/jps.2600640408

8. Chaudhary, M.; Parmar, S. S.; Chaudhary, S. K.; Chaturvedi, A. K.; Rama Sastry, B. V. J. Pharm. Sci. 1976, 65, 443-446. doi:10.1002/jps.2600650336

9. Turkevich, N. M.; Ladnaya, L. Y.; Pleshnev, I. V.; Grom, O. M. Khim. Issled. Farm. 1970, 64. Chem. Abstr. 1972, 76, 34154.

10. Nagar, S.; Singh, H. H.; Sinha, J. N.; Parmar, S. S. J. Med. Chem. 1973, 16, 178-180. doi:10.1021/jm00260a027

11. Ottaná, R.; Mazzon, E.; Dugo, L.; Monforte, F.; Maccari, R.; Sautebin, L.; De Luca, G.; Vigorita, M. G.; Alcaro, S.; Ortuso, F.; Caputi, A. P.; Cuzzocrea, S. Eur. J. Pharmacol. 2002, 448, 71-80. doi:10.1016/S0014-2999(02)01888-5

12. Blanchet, J.; Zhu, J. Tetrahedron Lett. 2004, 45, 4449-4452. doi:10.1016/j.tetlet.2004.04.055

13. Sedlák, M.; Hanusek, J.; Macháček, V.; Hejtmánková, L. J. Heterocycl. Chem. 2002, 39, 1105-1107. doi:10.1002/jhet.5570390543

14. Alizadeh, A.; Noaparast, Z.; Sabahno, H.; Zohreh, N. Helv. Chim. Acta 2010, 93, 1401-1406. doi:10.1002/hlca.200900402

15. Kasmi-Mir, S.; Djafri, A.; Paquin, L.; Hamelin, J.; Rahmouni, M. Molecules 2006, 11, 597-602. doi:10.3390/11080597

16. Saeed, A.; Abbas, N.; Flörke, U. J. Braz. Chem. Soc. 2007, 18, 559-565. doi:10.1590/S0103-50532007000300010

17. Yella, R.; Ghosh, H.; Patel, B. K. Green Chem. 2008, 10, 1307-1312. doi:10.1039/B807775D

18. St. Laurent, D. R.; Gao, Q.; Wu, D.; Serrano-Wu, M. H. Tetrahedron Lett. 2004, 45, 1907-1910. doi:10.1016/j.tetlet.2004.01.001

19. Sathishkumar, M.; Shanmugavelan, P.; Nagarajan, S.; Maheswari, M.; Dinesh, M.; Ponnuswamy, A. Tetrahedron Lett. 2011, 52, 2830-2833. doi:10.1016/j.tetlet.2011.03.069

20. Nagarajan, S.; Ran, P.; Shanmugavelan, P.; Sathishkumar, M.; Ponnusamy, A.; Nahm, K. S.; Gnanakumar, G. New J. Chem. 2012, 36, 1312-1319. doi:10.1039/c2nj40119c

21. Nagarajan, S.; Shanmugavelan, P.; Sathishkumar, M.; Priyadharshini, N.; Sudakar, P.; Ponnuswamy, A. Synth. Commun. 2013, 43, 668-680. doi:10.1080/00397911.2011.606043
22. Sathishkumar, M.; Palanikumar, K.; Mariappan, A.; Archana, S.; Ponnuswamy, A. J. Iran. Chem. Soc. 2012, 9, 681-685. doi:10.1007/s13738-012-0090-7

23. Shanmugavelan, P.; Sathishkumar, M.; Nagarajan, S.; Ponnuswamy, A. J. Heterocycl. Chem., in press.

24. Ponnuswamy, A.; Shanmugavelan, P.; Nagarajan, S.; Sathishkumar, M. Helv. Chim. Acta 2012, 95, 922-928. doi:10.1002/hlca.201100441

25. Shanmugavelan, P.; Nagarajan, S.; Sathishkumar, M.; Ponnuswamy, A.; Yogeeswari, P.; Sriram, D. Bioorg. Med. Chem. Lett. 2011, 21, 7273-7276. doi:10.1016/j.bmcl.2011.10.048

26. Shanmugavelan, P.; Sathishkumar, M.; Nagarajan, S.; Ponnuswamy, A. J. Chem. Sci. 2012, 124, 941-950. doi:10.1007/s12039-012-0281-x

27. Nagarajan, S.; Sathishkumar, M.; Shanmugavelan, P.; Ranganathan, R.; Ponnuswamy, A.; Venkatesan, R.; Shanmugaiah, V. Eur. J. Med. Chem. 2012, 58, 464-469. doi:10.1016/j.ejmech.2012.10.029

28. Ooi, C. W.; Fun, H.-K.; Quah, C. K.; Sathishkumar, M.; Ponnuswamy, A. Acta Crystallogr., Sect. E 2012, 68, o2563-2564. doi:10.1107/S1600536812033211

29. Ooi, C. W.; Fun, H.-K.; Quah, C. K.; Sathishkumar, M.; Ponnuswamy, A. Acta Crystallogr., Sect. E 2012, 68, o1994. doi:10.1107/S1600536812024646

30. Mamaghani, M.; Loghmanifar, A.; Taati, M. R. Ultrason. Sonochem. 2011, 18, 45-48. doi:10.1016/j.ultsonch.2010.05.009

31. Ottanà, R.; Maccari, R.; Barreca, M. L.; Bruno, G.; Rotondo, A.; Chiricosta, G.; Di Paola, R.; Sautebin, L.; Cuzzocrea, S.; Vigorita, M. G. Bioorg. Med. Chem. 2005, 13, 4243-4252. doi:10.1016/j.bmc.2005.04.058

32. Mavrova, A. T.; Anichina, K. K.; Vuchev, D. I.; Tsenov, J. A.; Kondeva, M. S.; Micheva, M. K. Bioorg. Med. Chem. 2005, 13, 5550-5559. doi:10.1016/j.bmc.2005.06.046

33. Kulakov, I. V. Russ. J. Org. Chem. 2009, 45, 1262-1263. doi:10.1134/S1070428009080296

34. Feng, Y.; Ding, X.; Chen, T.; Chen, L.; Liu, F.; Jia, X.; Luo, X.; Shen, X.; Chen, K.; Jiang, H.; Wang, H.; Liu, H.; Liu, D. J. Med. Chem. 2010, 53, 3465-3479. doi:10.1021/jm901004c

\section{License and Terms}

This is an Open Access article under the terms of the Creative Commons Attribution License (http://creativecommons.org/licenses/by/2.0), which permits unrestricted use, distribution, and reproduction in any medium, provided the original work is properly cited.

The license is subject to the Beilstein Journal of Organic Chemistry terms and conditions: (http://www.beilstein-journals.org/bjoc)

The definitive version of this article is the electronic one which can be found at: doi:10.3762/bjoc. 9.78 